\title{
New eremophilane and dichlororesorcinol derivatives produced by endophytes isolated from Ficus ampelas
}

\author{
Yoshihito Shiono $^{1}$, Niken Istikhari Muslihah ${ }^{1,2}$, Takuma Suzuki ${ }^{1}$, Nanang Rudianto Ariefta ${ }^{1,3}$, Chairil Anwar ${ }^{2}$, \\ Handojo Hadi Nurjanto ${ }^{4}$, Takako Aboshi ${ }^{1}$, Tetsuya Murayama ${ }^{1}$, Keitaro Tawaraya ${ }^{1}$, Takuya Koseki ${ }^{1}$, \\ Jun Yoshida ${ }^{5}$, Narandulam Usukhbayar ${ }^{3}$, Shota Uesugi ${ }^{3}$ and Ken-ichi Kimura ${ }^{3}$
}

The novel compound, 11-O-methylpetasitol (1), was isolated from Penicillium sp. N-175-1, and two new compounds, cosmochlorins D (5) and E (6), were isolated from Phomopsis sp. N-125. In addition, three known eremophilane sesquiterpenes, sporogen-AO1 (2), petasol (3) and 6-dehydropetasol (4), were isolated from Penicillium sp. N-175-1. The structures of 1, 5 and 6 were elucidated by a combination of extensive spectroscopic analyses, including 2D NMR, high-resolution electrospray ionization time-of-flight mass spectrometry (HRESITOFMS) and chemical reactions. Compounds 2, 3, 5 and 6 exhibited cytotoxicity to HL60 and 2 and 3 to HeLa cells. Furthermore, 2 and 3 showed robust growth-restoring activity of a Saccharomyces cerevisiae (cdc2-1 rad9A) mutant strain, whereas 5 and 6 exhibited minor growth-restoring activity in this strain. Thus, these compounds may inhibit the growth of HL60 and HeLa cells by blocking the cell cycle, and they may be utilized as new lead compounds that act as inhibitors of survival signal transduction pathways.

The Journal of Antibiotics (2017) 70, 1133-1137; doi:10.1038/ja.2017.125; published online 25 October 2017

\section{INTRODUCTION}

Endophytes are microorganisms living inside plant tissue without causing any diseases in the host plants. They are beneficial to the host plants, providing increased growth range, protection, plant survival, health and defense mechanisms. ${ }^{1}$ Therefore, endophytes can be utilized as biocontrol agents and have the potential for exploitation for other applications such as medicinal, agricultural and industrial purposes. ${ }^{2}$ Discovering novel and biologically active natural products from endophytes has received much research attention in recent years. ${ }^{3}$ In our ongoing search for new natural products from endophytes, the strains Penicillium sp. N-175-1 and Phomopsis sp. N-125 were found to be producers of novel secondary metabolites when cultured on steamed unpolished rice. These metabolites include the following three novel compounds: eremophilane sesquiterpene 11-O-methylpetasitol (1) isolated from $P$. sp. N-175-1 and dichlororesorcinol derivatives cosmochlorins D (5) and E (6) isolated from P. sp. N-125. Furthermore, the following three known eremophilane sesquiterpenes, sporogen-AO1 (2), petasol (3) and 6-dehydropetasol (4), were isolated from the N-175-1 strain. Herein, we report the isolation, structure elucidation and biological activities of these compounds.

\section{RESULTS AND DISCUSSION}

The structures of the known compounds, sporogen-AO1 (2), ${ }^{4}$ petasol $(3)^{5}$ and 6-dehydropetasol (4), ${ }^{6}$ were assigned by comparing their physicochemical properties and spectral data with those reported in the literature (Figure 1a).

Compound 1 was isolated as a white amorphous powder. Its molecular formula was determined to be $\mathrm{C}_{16} \mathrm{H}_{24} \mathrm{O}_{3}$ by high-resolution electrospray ionization time-of-flight mass spectrometry (HRESITOFMS). Its UV spectrum showed maximum absorbances at 243 and $314 \mathrm{~nm}$. The ${ }^{1} \mathrm{H}$ NMR spectrum of 1 exhibited the following signals: four methyls at $\delta_{\mathrm{H}} 1.14,1.25,1.45$ and 1.48 , one methoxy at $\delta_{\mathrm{H}} 3.21$, two olefinic protons at $\delta_{\mathrm{H}} 6.01$ and 7.10 , two $s p^{3}$ methines at $\delta_{\mathrm{H}} 3.66$ and 1.33 and two sets of methylene protons at $\delta_{\mathrm{H}} 1.40,2.24$, 2.37 and 2.50 (Table 1). A comprehensive analysis of the ${ }^{13} \mathrm{C} \mathrm{NMR}$ and DEPT spectra of $\mathbf{1}$ indicated 16 carbon signals due to the following groups: five methyls, two $s p^{3}$ methylenes, two $s p^{3}$ methines, two $s p^{2}$ methines and five quaternary carbons, including two olefinic carbons and one carbonyl carbon (Table 1). A partial structure, C-1, $\mathrm{C}-2, \mathrm{C}-3, \mathrm{C}-4$ and $\mathrm{C}-15$, was established based on the ${ }^{1} \mathrm{H}-{ }^{1} \mathrm{H}$ COSY spectrum as shown in Figure 1b. Among the isolated compounds, these spectroscopic features of 1 closely resembled those of 4 . The differences between $\mathbf{1}$ and $\mathbf{4}$ were the presence of both geminal methyls and a methoxy functionality in $\mathbf{1}$ instead of a vinylidene moiety in $\mathbf{4}$. The molecular formula of $\mathbf{1}$ differs from that of $\mathbf{4}$ by the addition of methanol $\left(\mathrm{CH}_{4} \mathrm{O}\right)$, and heteronuclear multiple bond correlation (HMBC) (Figure 1b) from Me-12 and Me-13 to C-7 and $\mathrm{C}-11$, and from Me-16 to C-11, suggesting that the vinylidene

${ }^{1}$ Department of Food, Life, and Environmental Science, Faculty of Agriculture, Yamagata University, Yamagata, Japan; ${ }^{2}$ Department of Chemistry, Faculty of Mathematics and Natural Sciences, Universitas Gadjah Mada, Yogyakarta, Indonesia; ${ }^{3}$ The United Graduate School of Agricultural Sciences, Iwate University, Iwate, Japan; ${ }^{4}$ Department of Silviculture, Faculty of Forestry, Universitas Gadjah Mada, Yogyakarta, Indonesia and ${ }^{5}$ Center for Liberal Arts and Sciences, Iwate Medical University, Iwate, Japan Correspondence: Professor Y Shiono, Department of Food, Life, and Environmental Science, Faculty of Agriculture, Yamagata University, 1-23 wakabamachi, Tsuruoka, Yamagata 997-8555, Japan.

E-mail: yshiono@tds1.tr.yamagata-u.ac.jp

Received 19 July 2017; revised 4 September 2017; accepted 7 September 2017; published online 25 October 2017 
a<smiles>[2H]C1=C[C@@]2(C)[C@H](C)[C@H](O)CC[C@@H]2C=CC1=O</smiles><smiles>C=C=CC(C)C(C)(C)OC</smiles><smiles>C=C(C)[C@@]12O[C@H]1[C@@]1(C)C(=CC2=O)CC[C@@H](O)[C@@H]1C</smiles>
2<smiles>C=C(C)[C@H]1C[C@]2(C)C(=CC1=O)CC[C@H](O)[C@@H]2C</smiles>
3<smiles>[R]c1c(Cl)c(OC)cc(OC)c1Cl</smiles>

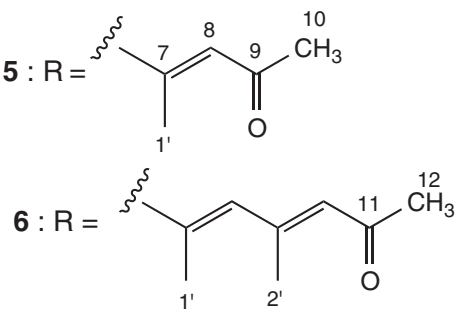

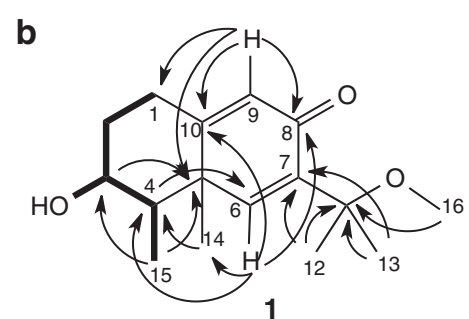

C

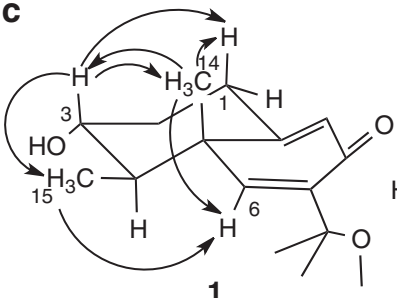

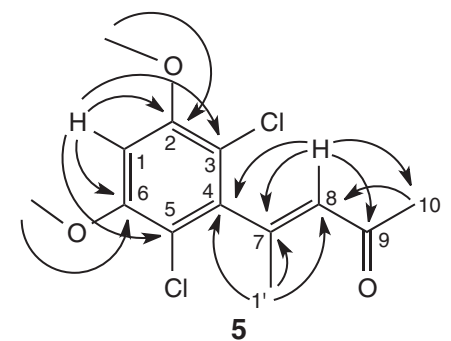

5<smiles>CCC(CC)c1c(OC)c(Cl)c(C)c(Cl)c1OC</smiles>

5<smiles>C=CC=C(C)C(C)=C(C)C(C)=O</smiles>

6

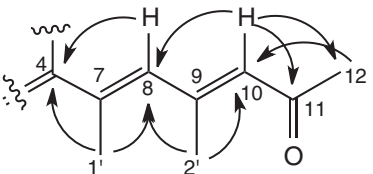

6

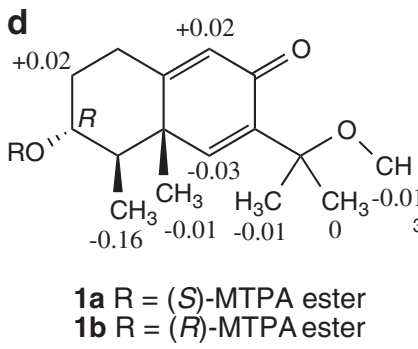

Figure 1 11-O-Methylpetasitol (1), sporogen-AO1 (2), petasol (3) and 6-dehydropetasol (4), cosmochlorins $\mathrm{D}(\mathbf{5})$ and $\mathrm{E}(\mathbf{6})$ : (a) structures of $\mathbf{1 - 6}$, (b) ${ }^{1} \mathrm{H}-{ }^{1} \mathrm{H}$ COSY (bold) for $\mathbf{1}$ and key HMBC (arrows) observed for 1, $\mathbf{5}$ and 6, (c) key NOE correlations observed for 1, $\mathbf{5}$ and $\mathbf{6}$, (d) chemical shift differences for the $(S)-(-)$ MTPA ester (1a) and (R)-(+)-MTPA ester (1b) in ppm. HMBC, heteronuclear multiple bond correlation; MTPA, $\alpha$-methoxy- $\alpha$-trifluoromethylphenylacetic acid.

moiety of $\mathbf{4}$ has been saturated in $\mathbf{1}$ by the addition of methanol. Moreover, the data from $\mathrm{HMBC}$ experiments allowed all of the protons and carbons to be assigned. The relative stereochemistry for $\mathbf{1}$ was determined by a combination of NOE experiments and measurement of the carbon chemical shifts and proton-proton coupling constants. In the NOE difference spectra of 1 , NOEs from $\mathrm{H}-1$ to $\mathrm{H}-3$ and from $\mathrm{H}-3$ to Me-14 and Me-15 indicated that $\mathrm{H}-3, \mathrm{Me}-14$ and Me-15 exhibited $\beta$-configurations (Figure 1c). These findings allowed the assignment of a relative stereostructure to $3 \alpha$-hydroxy-11-methoxy-8-oxoeremophila-6,9-diene. The absolute configuration of C-3 was elucidated by applying a modified version of Mosher's method ${ }^{7}$ (Figure 1d). Consequently, we found that $\mathbf{1}$ was an analog of petasitin isolated from the edible plant, Petasites japonicus Maxim. ${ }^{8}$ The structure of this analog was found to be an 11-methoxy derivative of petasitol that was a hydrolysate of petasitin. ${ }^{9}$

Cosmochlorin D (5) was obtained as a white amorphous powder. HRESITOFMS measurement of the positive molecular ion of $\mathbf{5}$ indicated the molecular formula, $\mathrm{C}_{13} \mathrm{H}_{14} \mathrm{Cl}_{2} \mathrm{O}_{3}$. The UV maxima at 234 and $297 \mathrm{~nm}$ were indicative of a conjugated chromophore. The ${ }^{1} \mathrm{H}$ and ${ }^{13} \mathrm{C}$ NMR and DEPT spectra revealed the presence of an aromatic ring that comprised a pentasubstituted benzene ring with two oxygenated carbons $\left(\delta_{\mathrm{C}} 96.6,155.1(2 \times \mathrm{C}), 111.4(2 \times \mathrm{C}), 142.3\right.$ and $\left.\delta_{\mathrm{H}} 6.78\right)$, a trisubstituted double bond $\left(\delta_{\mathrm{C}} 151.2,127.9\right.$ and $\delta_{\mathrm{H}}$ 6.15), an olefinic methyl $\left(\delta_{\mathrm{H}} 2.29\right)$ and an acetyl moiety $\left(\delta_{\mathrm{C}} 30.7,199.8\right.$ and $\delta_{\mathrm{H}} 2.25$ ) (Table 2). These partial structures were found to be connected through the long-range correlations by HMBC experiments as shown in Figure 1b. The HMBC from $\mathrm{H}-10$ to C-8 and from $\mathrm{H}-8$ and Me-1' to C-4 demonstrated that a 3-penten-2-one moiety (C-7C-10 and C-1') was attached at C-4 of the benzene ring. Two methoxy groups and two chlorine atoms were also attached to the carbons of the benzene ring. The benzene ring-substituted pattern of 5 was deduced from the analysis of the NOE difference experiments (Figure 1c). Two methoxy groups could be assigned as substituents at C-2 and C- 6 of the pentasubstituted phenyl group based on the observable NOE correlations between $\mathrm{OMe}-2$ and $\mathrm{H}-1$, and between OMe-6 and $\mathrm{H}-1$. According to the ${ }^{13} \mathrm{C}$ chemical shift of the allylic methyl carbon C-1' $\left(\delta_{\mathrm{C}} 18.3\right)$, the stereochemistry of $\mathrm{C}(7)=\mathrm{C}(8)$ within the butenone moiety was deduced to be $E \cdot{ }^{10}$ In addition, no NOE difference between Me-1' and H-8 was observed. 
Table $1{ }^{1} \mathrm{H}(600 \mathrm{MHz})$ and ${ }^{13} \mathrm{C}(150 \mathrm{MHz})$ NMR spectral data of 1 in $\mathrm{CDCl}_{3}$

\begin{tabular}{|c|c|c|c|}
\hline No & $\delta_{C}$ & $\delta_{H}$, mult. $(J$ in $\mathrm{Hz})$ & $H M B C$ \\
\hline \multirow[t]{2}{*}{1} & $30.2 \mathrm{t}$ & $2.37 \mathrm{td}(13.1,2.1)$ & $3,5,9$ \\
\hline & & 2.50 td $(13.1,4.9)$ & $3,5,9$ \\
\hline \multirow[t]{2}{*}{2} & $36.5 \mathrm{t}$ & $1.40 \mathrm{~m}$ & 4,10 \\
\hline & & $2.24 \mathrm{~m}$ & 10 \\
\hline 3 & $71.4 \mathrm{~d}$ & $3.66 \mathrm{td}(10.5,6.2)$ & $1,5,15$ \\
\hline 4 & $47.4 \mathrm{~d}$ & $1.33 \mathrm{~m}$ & $2,6,10,14,15$ \\
\hline 5 & $42.8 \mathrm{~s}$ & & \\
\hline 6 & $150.4 \mathrm{~d}$ & $7.10 \mathrm{~s}$ & $8,10,14$ \\
\hline 7 & $139.5 \mathrm{~s}$ & & \\
\hline 8 & $185.8 \mathrm{~s}$ & & \\
\hline 9 & $125.8 \mathrm{~d}$ & $6.01 \mathrm{~s}$ & $1,5,7$ \\
\hline 10 & $165.0 \mathrm{~s}$ & & \\
\hline 11 & $76.0 \mathrm{~s}$ & & \\
\hline 12 & $24.7 \mathrm{q}$ & $1.48 \mathrm{~s}$ & $7,11,13$ \\
\hline 13 & $26.0 \mathrm{q}$ & $1.45 \mathrm{~s}$ & $7,11,12$ \\
\hline 14 & $18.9 \mathrm{q}$ & $1.14 \mathrm{~s}$ & $4,5,6,10$ \\
\hline 15 & $12.0 \mathrm{q}$ & $1.25 \mathrm{~d}(6.6)$ & $3,4,5$ \\
\hline 16 & $49.9 \mathrm{q}$ & $3.21 \mathrm{~s}$ & 11 \\
\hline
\end{tabular}

Abbreviation: $\mathrm{HMBC}$, heteronuclear multiple bond correlation.

Cosmochlorin E (6) was isolated as a white amorphous powder with a molecular formula of $\mathrm{C}_{16} \mathrm{H}_{18} \mathrm{Cl}_{2} \mathrm{O}_{3}$, as determined by HRESITOFMS. The NMR spectra of $\mathbf{6}$ contained features closely resembling the NMR spectra of $\mathbf{5}$, except for the presence of an additional olefinic signal $\left(\delta_{\mathrm{C}} 143.2,125.9\right.$ and $\left.\delta_{\mathrm{H}} 5.79\right)$ and an additional methyl group $\left(\delta_{\mathrm{C}} 17.5\right.$ and $\delta_{\mathrm{H}} 2.25$ ) (Table 2). The NMR spectra of 6 contained signals corresponding to the pentasubstituted benzene ring $\left(\delta_{\mathrm{C}} 96.3\right.$, $154.9(2 \times \mathrm{C}), 112.4(2 \times \mathrm{C}), 137.7$ and $\left.\delta_{\mathrm{H}} 6.74\right)$. Hence, the structural differences between 5 and $\mathbf{6}$ consist of the side chain attached to the benzene ring portion of the structure. In the HMBC spectrum of 6 (Figure 1b), correlations were observed from Me-12 to C-10, from $\mathrm{H}-10$ to C-8, from Me-2' to C-8 and C-10 and from Me-1' to C-8, suggesting the presence of a 4-methyl-hepta-3,5-dien-2-one moiety. Furthermore, HMBC from Me-1' and $\mathrm{H}-8$ to C-4 showed that this heptadienone moiety was located at C-4. The geometries of two olefins at C-7/C-8 and C-9/C-10 of the hexadienone moiety were found to be $E$ based on NOE correlations between H-8 and H-10 (Figure 1c).

The isolated compounds were assayed for their cytotoxic activity in HL60 ( IC $_{50} ; 1$ : $>100 \mu \mathrm{M}, 2: 2.1 \mu \mathrm{M}, 3: 4.4 \mu \mathrm{M}, 4:>100 \mu \mathrm{M}, 5: 6.1 \mu \mathrm{M}$ and 6: $1.8 \mu \mathrm{M})$ and HeLa cells $\left(\mathrm{IC}_{50} ; 1\right.$ : $>100 \mu \mathrm{M}, 2: 22.6 \mu \mathrm{M}, 3$ : $68.6 \mu \mathrm{M}, 4:>100 \mu \mathrm{M}, 5:>100 \mu \mathrm{M}$ and 6: $>100 \mu \mathrm{M})$. In both cell types, the $\mathrm{IC}_{50}$ values of $\mathbf{2}$ and 3 were lower than those of $\mathbf{1}$ and $\mathbf{4}$, suggesting that the absence of the double bond between C- 6 and C-7 is crucial for cytotoxic activity. The epoxy ring also contributes to the cytotoxicity, as supported by a previous report. ${ }^{11}$ Other eremophilane sesquiterpenes having identical or similar skeletons as $\mathbf{1 - 4}$ have been isolated from plants and fungi. Several of these eremophilane sesquiterpenes exhibited diverse biological activities such as antimicrobial, ${ }^{12,13}$ cytotoxic, ${ }^{14}$ anti-HIV ${ }^{15}$ or calcineurin inhibition. ${ }^{16}$

Cosmochlorins A and B, which share the same core skeleton as $\mathbf{5}$ and 6 , have been shown to partially restore the growth inhibition induced by hyperactivated $\mathrm{Ca}^{2+}$ signaling in the $S$. cerevisiae mutant YNS17 strain $(z d s 1 \Delta \operatorname{erg} 3 \Delta p d r 1 \Delta p d r 3 \Delta)$ through glycogen synthase kinase-3 $\beta$ inhibition. ${ }^{17}$ Compounds $\mathbf{5}$ and $\mathbf{6}$ exhibited stronger cytotoxicity in HL60 cells compared with cosmochlorins A and B $\left(\mathrm{IC}_{50}(\mu \mathrm{M}) ; 73.7\right.$ and 53.6, respectively). Compounds 5 and $\mathbf{6}$ also
Table $2{ }^{1} \mathrm{H}(600 \mathrm{MHz})$ and ${ }^{13} \mathrm{C}(150 \mathrm{MHz})$ NMR spectral data for 5 and 6 in $\mathrm{CD}_{3} \mathrm{OD}$

\begin{tabular}{|c|c|c|c|c|c|c|}
\hline \multirow[b]{3}{*}{ No. } & \multicolumn{3}{|c|}{5} & \multicolumn{3}{|c|}{6} \\
\hline & & $\delta_{H}$, mult. (J & & & $\delta_{H}$, mult. (J & \\
\hline & $\delta_{C}$ & in $\mathrm{Hz}$ ) & $H M B C$ & $\delta_{C}$ & in $\mathrm{Hz}$ ) & $H M B C$ \\
\hline 1 & $96.6 \mathrm{~d}$ & $6.78 \mathrm{~s}$ & $2,3,5,6$ & $96.3 \mathrm{~d}$ & $6.74 \mathrm{~s}$ & $2,3,5,6$ \\
\hline 2,6 & $155.1 \mathrm{~s}$ & & & $154.9 \mathrm{~s}$ & & \\
\hline 3,5 & $111.4 \mathrm{~s}$ & & & $112.4 \mathrm{~s}$ & & \\
\hline 4 & $142.3 \mathrm{~s}$ & & & $137.7 \mathrm{~s}$ & & \\
\hline 7 & $151.2 \mathrm{~s}$ & & & $143.2 \mathrm{~s}$ & & \\
\hline 8 & $127.9 \mathrm{~d}$ & $6.15 \mathrm{~d}(1.4)$ & $\begin{array}{l}4,7 \\
9,10\end{array}$ & $125.9 \mathrm{~d}$ & 5.79 br.s & $4,10,1^{\prime}$ \\
\hline 9 & $199.8 \mathrm{~s}$ & & & $151.5 \mathrm{~s}$ & & \\
\hline $\begin{array}{l}10 \\
11\end{array}$ & 30.7 q & $2.25 \mathrm{~s}$ & 8,9 & $\begin{array}{l}133.5 \mathrm{~d} \\
200.1 \mathrm{~s}\end{array}$ & 6.30 br.s & $8,12,2^{\prime}$ \\
\hline 12 & & & & 30.7 q & $2.23 \mathrm{~s}$ & 10,11 \\
\hline $1^{\prime}$ & $18.3 \mathrm{q}$ & $2.29 \mathrm{~d}(1.4)$ & $4,7,8$ & $18.3 \mathrm{q}$ & $2.05 \mathrm{~d}(1.3)$ & $4,7,8$ \\
\hline $2^{\prime}$ & & & & $17.5 \mathrm{q}$ & 2.25 br.s & $8,9,10$ \\
\hline 2, 6-OMe & $55.8 \mathrm{q}$ & $3.93 \mathrm{~s}$ & 2,6 & 55.7 q & $3.90 \mathrm{~s}$ & 2,6 \\
\hline
\end{tabular}

showed growth-inhibition activity and not growth-restoring activity to the YNS17 strain with hyperactivated $\mathrm{Ca}^{2+}$ signal transduction (Supplementary Figure S14). As expected, the glycogen synthase kinase- $3 \beta$ inhibition activity of cosmochlorins $\mathrm{A}$ and $\mathrm{B}$ were significantly higher than compounds 5 and 6 (5: 50.9 and 6: $56.2 \%$ at $200 \mu \mathrm{M})$.

We further examined the biological activities of the isolated compounds. Another mutant yeast screening system was used to search for antitumor agents through the inhibition of the cell cycle. ${ }^{18,19}$ The mutant strain S. cerevisiae ( $c d c 2-1 \mathrm{rad} 9 \Delta$ ) cannot grow at $28^{\circ} \mathrm{C}$ after incubation for $6 \mathrm{~h}$ at $37^{\circ} \mathrm{C}$ because it rapidly loses its viability at $37^{\circ} \mathrm{C}$. In fact, thiabendazole or hydroxyurea was detected in this mutant strain after restoration of growth, because of its ability to arrest cell cycle progression via the cell cycle checkpoint pathway. ${ }^{19}$ In other words, this assay system can screen compounds that have a unique mode of antitumor activity in a xenograft model. ${ }^{20} \mathrm{We}$ clarified the growth-restoring activity of several antitumor compounds such as AG1024, wortmannin, staurosporine, TX-1918 and rapamycin (Supplementary Figure S15). Under this screening system, 2 and 3 exhibited clear growth-restoring activities of the mutant yeast in a dose-dependent manner. In contrast, 5 and $\mathbf{6}$ showed minor growthrestoring ability because of having anti-yeast activity (Figure 2). In addition, the growth-restoring activities of the compounds in the mutant yeast depended on their cytotoxic activities. In fact, 2 and $\mathbf{3}$, which exhibited high cytotoxicity in both HL60 and HeLa cells, had a positive effect on growth at the concentrations of 0.625 and $1.25 \mu \mathrm{g}$ per spot, respectively. These data suggest that the cytotoxicities compounds are correlated with their ability to restore the growth of the mutant yeast that may involve survival signal transduction in human cells. Although further investigation of the mechanism of action of 2, 3, 5 and $\mathbf{6}$ is warranted, these compounds may inhibit the growth of HL60 or HeLa cells by blocking the cell cycle. Thus, these compounds may be new lead compounds that function as inhibitors of survival signal transduction pathways.

(3R)-11-O-Methylpetasitol (1)

White amorphous powder; $[\alpha]_{\mathrm{D}}{ }^{20}+143.0$ (c $\left.0.01, \mathrm{MeOH}\right)$; UV $(\mathrm{MeOH}) \lambda_{\max }(\log \varepsilon): 243$ (4.3), 314 (2.9) nm; IR (KBr) $\nu_{\max }$ 
a

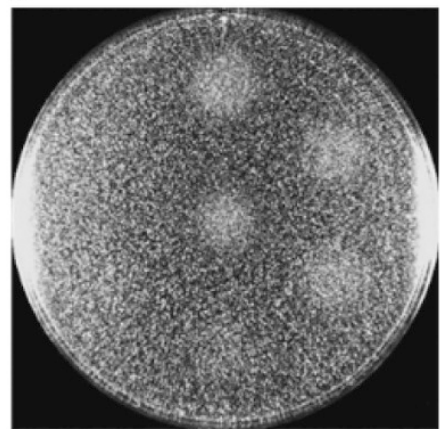

C

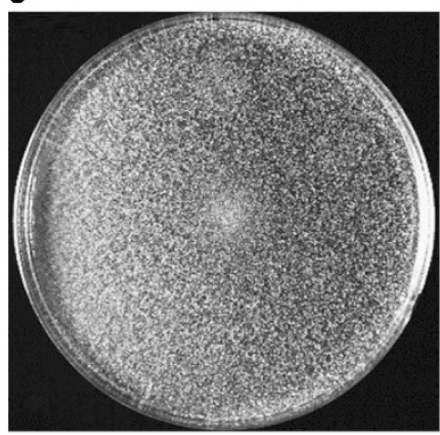

b

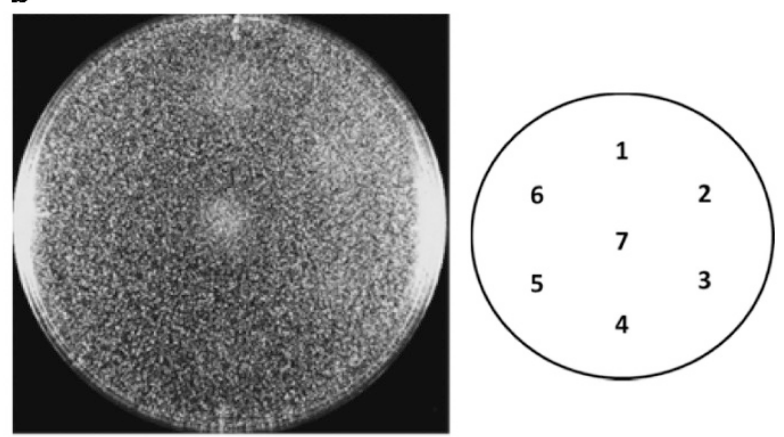

d

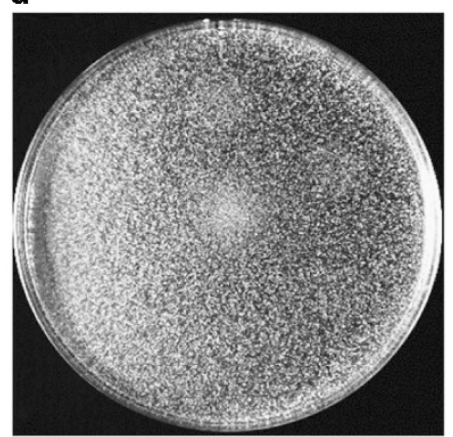

Figure 2 Growth-restoring activities of 2 (a), 3 (b), 5 (c) and $\mathbf{6}$ (d) against $S$. cerevisiae (cdc2-1 rad9A). 1: $5.0 \mu \mathrm{g}$ per spot, 2: $2.5 \mu \mathrm{g}$ per spot, $3: 1.25 \mu \mathrm{g}$ per spot, 4. $0.625 \mu \mathrm{g}$ per spot, 5: $0.313 \mu \mathrm{g}$ per spot, 6: $0.156 \mu \mathrm{g}$ per spot, 7: $1.25 \mathrm{mg}$ per spot (hydroxyurea).

$\mathrm{cm}^{-1}: 3325,2913,2715,1720,1643,1268,1187 ;{ }^{1} \mathrm{H}$ and ${ }^{13} \mathrm{C}$ NMR see Table 1; HRESITOFMS $m / z 265.1779[\mathrm{M}+\mathrm{H}]^{+}$(calcd for $\mathrm{C}_{16} \mathrm{H}_{25} \mathrm{O}_{3}$, 265.1804).

\section{Cosmochlorin D (5)}

White amorphous powder; UV $(\mathrm{MeOH}) \lambda_{\max }(\log \varepsilon): 234$ (4.1), 297 (2.0) nm; IR (KBr) $\nu_{\max } \mathrm{cm}^{-1}: 2983,2933,1680,1583,1176,999 ;{ }^{1} \mathrm{H}$ and ${ }^{13} \mathrm{C}$ NMR see Table 2; HRESITOFMS $m / z 289.0396[\mathrm{M}+\mathrm{H}]^{+}$ (calcd for $\mathrm{C}_{13} \mathrm{H}_{15}{ }^{35} \mathrm{Cl}_{2} \mathrm{O}_{3}, 289.0398$ ), $\mathrm{m} / z 291.0366[\mathrm{M}+\mathrm{H}]^{+}$(calcd for $\mathrm{C}_{13} \mathrm{H}_{15}{ }^{35} \mathrm{Cl}^{37} \mathrm{ClO}_{3}, 289.0369$ ), and $\mathrm{m} / z 293.0336[\mathrm{M}+\mathrm{H}]^{+}$(calcd for $\left.\mathrm{C}_{13} \mathrm{H}_{15}{ }^{37} \mathrm{Cl}_{2} \mathrm{O}_{3}, 293.0339\right)$.

\section{Cosmochlorin E (6)}

White amorphous powder; UV (MeOH) $\lambda_{\max }(\log \varepsilon): 287(4.0) \mathrm{nm}$; IR $(\mathrm{KBr}) \nu_{\max } \mathrm{cm}^{-1}: 2994,2926,1681,1555,1177,996 ;{ }^{1} \mathrm{H}$ and ${ }^{13} \mathrm{C}$ NMR see Table 2; HRESITOFMS $\mathrm{m} / \mathrm{z} 329.0710 \quad[\mathrm{M}+\mathrm{H}]^{+}$ (calcd for $\mathrm{C}_{16} \mathrm{H}_{19}{ }^{35} \mathrm{Cl}_{2} \mathrm{O}_{3}, 329.0711$ ), $\mathrm{m} / z 331.0689[\mathrm{M}+\mathrm{H}]^{+}$(calcd for $\mathrm{C}_{16} \mathrm{H}_{19}{ }^{35} \mathrm{Cl}^{37} \mathrm{ClO}_{3}, 331.0682$ ) and $m / z 333.5658[\mathrm{M}+\mathrm{H}]^{+}$(calcd for $\mathrm{C}_{16} \mathrm{H}_{19}{ }^{37} \mathrm{Cl}_{2} \mathrm{O}_{3}, 333.0652$ ).

\section{CONFLICT OF INTEREST}

The authors declare no conflict of interest.

\section{ACKNOWLEDGEMENTS}

We thank Emeritus Professor Eiko Tsuchiya of Hiroshima University for giving us a mutant strain, Saccharomyces cerevisiae (cdc2-1 rad9s), and Japan Student Services Organization (JASSO, the Student Exchange Support Program) for the scholarship to NIM. This work was partly supported by MEXT KAKENHI Grant Number JP15H05246.
1 Deng, Z. \& Cao, L. Fungal endophytes and their interactions with plants in phytoremediation. Chemosphere 168, 1100-1106 (2017).

2 Kusari, S., Hertweck, C. \& Spiteller, M. Chemical ecology of endophytic fungi: origins of secondary metabolites. Chem. Biol. 19, 792-798 (2012).

3 Patil, R. H., Patil, M. P. \& Maheshwari, V. L. Bioactive secondary metabolites from endophytic fungi: a review of biotechnological production and their potential applications. Stud. Nat. Prod. Chem. 49, 189-205 (2016).

4 Tirilly, Y., Kloosterman, J., Sipma, G. \& Kettenes-Van Den Bosch, J. J. A fungitoxic sesquiterpene from Hansfordia pulvinata. Phytochemistry 22, 2082-2083 (1983).

5 Sugama, K., Hayashi, K., Nakagawa, T., Mitsuhashi, H. \& Yoshida, N. Sesquiterpenoids from Petasites fragrans. Phytochemistry 22, 1619-1622 (1983).

6 Sugawara, F. et al. Phytoactive eremophilanes produced by the weed pathogen Drechslera gigantea. Biosci. Biotechnol. Biochem. 57, 236-239 (1993).

7 Ohtani, I., Kusumi, T., Kashman, H. \& Kakisawa, H. The absolute configurations of marine terpenoids. J. Am. Chem. Soc. 113, 4092-4096 (1991).

8 Naya, K. \& Takagi, I. The structure of petasitin, a new sesquiterpene from Petasites japonicus Maxim. Tetrahed. Lett. 5, 629-632 (1968).

9 Takagi, I., Tazuke, Y. \& Naya, K. The components of Petasites japonicus Maxim. IV. The structure of petasitin. Bull. Chem. Soc. Jpn 50, 3320-3323 (1977).

10 Yan, X. H., Gavagnin, M., Cimino, G. \& Guo, Y. W. Two new biscembranes with unprecedented carbon skeleton and their probable biogenetic precursor from the Hainan soft coral Sarcophyton latum. Tetrahed. Lett. 48, 5313-5316 (2007).

11 Motohashi, K. et al. New sesquiterpenes, JBIR-27 and -28, isolated from a tunicatederived fungus, Penicillium sp. SS080624SCf1. J. Antibiot. 62, 247-250 (2009).

12 Hatakeyama, T., Koseki, T., Murayama, T. \& Shiono, Y. Eremophilane sesquiterpenes from the endophyte Microdiplodia sp. KS 75-1 and revision of the stereochemistries of phomadecalins C and D. Phytochem. Lett. 3, 148-151 (2010).

13 Le, D. H., Takenaka, Y, Hamada, N. \& Tanahashi, T. Eremophilane-type sesquiterpenes from cultured lichen mycobionts of Sarcographa tricosa. Phytochemistry 91, 242-248 (2013).

14 Huang, Y. F., Qiao, L., Li, Lv, A., Peib, Y. H. \& Tian, L. Eremophilane sesquiterenes from the marine fungus Penicillium sp. BL27-2. Chin. Chem. Lett. 19, 562-564 (2008).

15 Singh, S. B. et al. Structure and absolute stereochemistry of HIV-1 integrase inhibitor integric acid. A novel eremophilane sesquiterpenoid produced by a Xylaria sp. Tetrahed. Lett. 40, 8775-8779 (1999).

16 Ogasawara, Y., Yoshida, J., Shiono, Y., Miyakawa, T. \& Kimura, K. New eremophilane sesquiterpenoid compounds, eremoxylarins $A$ and $B$ directly inhibit calcineurin in a manner independent of immunophilin. J. Antibiot. 61, 496-502 (2008).

17 Shiono, Y. et al. GSK-3 $\beta$ inhibitory activities of novel dichlororesorcinol derivatives from Cosmospora vilior isolated from a mangrove plant. Phytochem. Lett. 18, 122-127 (2016).

18 Tsuchiya, E., Yukawa, M., Miyakawa, T., Kimura., K. \& Takahashi, H. Borrelidin inhibits a cyclin-dependent kinase (CDK), Cdc28/Cln2, of Saccharomyces cerevisiae. J. Antibiot. 54, 84-90 (2010). 
19 Tsuchiya, E., Yukawa, M., Ueno, M., Kimura, K. \& Takahashi, H. A novel method of screening cell-cycle blockers as candidates for anti-tumor reagents using yeast as a screening tool. Biosci. Biotechnol. Biochem. 74, 411-414 (2010).
20 Kimura, K. et al. Cleavage mechanism and anti-tumor activity of 3,6-epidioxy-1,10bisaboladiene isolated from edible wild plants. Bioorg. Med. Chem. 20, 3887-3897 (2012)

Supplementary Information accompanies the paper on The Journal of Antibiotics website (http://www.nature.com/ja) 